\title{
Use of bovine follicular fluid to increase ovulation rate or prevent ovulation in sheep
}

\author{
K. M. Henderson, M. D. Prisk, N. Hudson, K. Ball, K. P. McNatty, S. Lun, \\ D. Heath, L. E. Kieboom and J. McDiarmid
}

Wallaceville Animal Research Centre, Research Division, Ministry of Agriculture and Fisheries, Private Bag, Upper Hutt, New Zealand

\begin{abstract}
Summary. Romney ewes were injected intramuscularly once or twice daily for 3 days with $0,0 \cdot 1,0 \cdot 5,1$ or $5 \mathrm{ml}$ of bovine follicular fluid (bFF) treated with dextran-coated charcoal, starting immediately after injection of cloprostenol to initiate luteolysis on Day 10 of the oestrous cycle. There was a dose-related suppression of plasma concentrations of FSH, but not $\mathrm{LH}$, during the treatment period. On stopping the bFF treatment, plasma FSH concentrations 'rebounded' to levels up to 3-fold higher than pretreatment values. The mean time to the onset of oestrus was also increased in a dose-related manner by up to 11 days. The mean ovulation rates of ewes receiving $1.0 \mathrm{ml}$ bFF twice daily ( $1.9 \pm 0.2$ ovulations/ewe, mean \pm s.e.m. for $\mathrm{N}=34)$ or $5.0 \mathrm{ml}$ once daily $(2 \cdot 0 \pm 0 \cdot 2$ ovulations/ewe, $\mathrm{N}=25)$ were significantly higher than that of control ewes (1.4 $\pm 0 \cdot 1$ ovulations/ewe, $N=35)$. Comparison of the ovaries of ewes treated with bFF for 24 or $48 \mathrm{~h}$ with the ovaries of control ewes revealed no differences in the number or size distribution of antral follicles. However, the large follicles ( $\geqslant 5 \mathrm{~mm}$ diam.) of bFF-treated ewes had lower concentrations of oestradiol-173 in follicular fluid, contained fewer granulosa cells and the granulosa cells had a reduced capacity to aromatize testosterone to oestradiol-17 $\beta$ and produce cyclic AMP when challenged with FSH or LH. No significant effects of bFF treatment were observed in small (1-2.5 mm diam.) or medium (3-4.5 mm diam.) sized follicles. Ewes receiving $5 \mathrm{ml} \mathrm{bFF}$ once daily for 27 days, from the onset of luteolysis, were rendered infertile during this treatment period. Oestrus was not observed and ovulation did not occur. Median concentrations of plasma FSH fell to $20 \%$ of pretreatment values within 2 days. Thereafter they gradually rose over the next 8 days to reach $60 \%$ of pretreatment values where they remained for the rest of the 27-day treatment period. Median concentrations of plasma LH increased during the treatment period to levels up to 6-fold higher than pretreatment values. When bFF treatment was stopped, plasma concentrations of FSH and LH quickly returned to control levels, and oestrus was observed within 2 weeks. The ewes were mated at this first oestrus and each subsequently delivered a single lamb.
\end{abstract}

\section{Introduction}

Follicular fluid is reported to contain a number of non-steroidal compounds including inhibin (Henderson, Franchimont, Charlet-Renard \& McNatty, 1984), ovarian inhibitory protein (Kling et al., 1984), oocyte maturation inhibitor (Channing et al., 1982a), luteinization inhibitors (Ledwitz-Rigby et al., 1977) and follicle-stimulating hormone receptor binding inhibitor (Sluss, Fletcher \& Reichert, 1983), each of which may be important in regulating reproductive function. Administration of steroid-free bovine follicular fluid (bFF) to ewes specifically suppresses plasma concentrations of follicle-stimulating hormone (FSH), and delays the onset of oestrus if 
administered during the preovulatory period (Miller, Critser, Rowe \& Ginther, 1979; Cummins, O'Shea, Bindon, Lee \& Findlay, 1983; McNeilly, 1984); these effects have been attributed to the inhibin content of follicular fluid. Although plasma FSH concentrations are suppressed during treatment of ewes with bFF, they 'rebound' to levels considerably higher than pretreatment values within $24-36 \mathrm{~h}$ of stopping the bFF treatment (Miller, Critser \& Ginther, 1982; McNeilly, 1984). Since FSH, or FSH-like substances can be used to increase ovulation rate in sheep (Wright, Bondioli, Grammer, Kuzan \& Menino, 1981; Boland, Crosby \& Gordon, 1983; Kelly, Owens, Crosbie, McNatty \& Hudson, 1983; McNatty et al., 1985), it is possible that using bFF treatment to raise plasma concentrations of FSH might provide a means of increasing ovulation rate in sheep. This possibility was investigated in the present study which was undertaken to examine the effects of short-term ( 3 days) and long-term (27 days) bFF treatment on plasma gonadotrophin concentrations, follicular function and reproductive activity in Romney ewes.

\section{Materials and Methods}

\section{Preparation of follicular fluid and plasma}

Ovaries were obtained at slaughter from cows at a local abattoir over a 6-month period. At each collection, all antral follicles visible on the surface of the ovaries were punctured with a 20-gauge needle, and the follicular fluid was aspirated under vacuum. Debris and red blood cells were removed from the pooled fluids by centrifugation at $1200 \mathrm{~g}$ for $15 \mathrm{~min}$ at $4^{\circ} \mathrm{C}$, and the supernatant was stored frozen at $-20^{\circ} \mathrm{C}$ until later use. Once an adequate volume of fluid had been collected, the fluids were thawed, pooled and steroids removed as described previously (Henderson \& Franchimont, 1981) by mixing for $16 \mathrm{~h}$ at $4^{\circ} \mathrm{C}$ with activated charcoal (Norit A, 1\%, Fisher Scientific Co., Springfield, New Jersey, U.S.A.) pretreated with dextran T-70 ( $0 \cdot 1 \%$ Pharmacia Fine Chemicals AB, Uppsala, Sweden) followed by centrifugation at $3000 \mathrm{~g}$ (twice) and filtration of the supernatant (Whatman No. 1). The filtrate was stored frozen at $-20^{\circ} \mathrm{C}$ in volumes of $10-100 \mathrm{ml}$ until required. The experiments in this study were performed using a single batch of bovine follicular fluid (bFF) in which dextran-coated charcoal treatment had reduced the concentrations of oestradiol- $17 \beta$, androstenedione, testosterone and progesterone to $<1 \%$ of their original values.

Plasma prepared from jugular venous blood taken from an ovariectomized Angus cow was pooled and treated with dextran-coated charcoal as described above for bFF. This was stored frozen in aliquants until required for treating control ewes.

\section{Sheep, treatments and blood sampling}

Parous New Zealand Romney ewes (aged 2.5-3.5 years and weighing about $50-60 \mathrm{~kg}$ ) were used in this study. They were grazed on open pasture and run with a vasectomized ram fitted with a marking harness. The ewes were examined twice daily for signs of oestrus. The basic experimental procedure was as follows. On the 10th day after oestrus was observed (Day 0 of an experiment) jugular venous blood samples $(\sim 2 \mathrm{ml})$ were taken from ewes in the morning $(08: 30 \mathrm{~h})$ and afternoon $(16: 30 \mathrm{~h})$. The following morning (Day 1, 08:30 h), the ewes were bled again and given an intramuscular (i.m.) injection of the prostaglandin F-2 $\alpha$ analogue, cloprostenol (125 $\mu \mathrm{g}$ : ICI Tasman Ltd, Upper Hutt, N.Z.) to initiate luteolysis. Immediately afterwards the ewes were injected (i.m.) with $0 \cdot 1-5.0 \mathrm{ml}$ bFF (treated ewes) or plasma from an ovariectomized cow (control ewes). Morning, or morning and afternoon, injections of follicular fluid or plasma were continued until the afternoon of Day 3 of the experiment. Twice daily blood samples were taken until the afternoon of Day 3, thereafter once daily blood samples were taken through to Day 11 of the experiment. Blood samples were taken immediately before any injections of bFF or plasma. The number of 
ovulations (ovulation rate) was determined by laparoscopic examination of the ovaries of each ewe, 9-12 days after oestrus was observed, and counting the number of corpora lutea present. In modifications of this procedure, some ewes were treated with bFF or plasma and subjected to laparoscopy as above, but no blood samples were taken. In other ewes, ovariectomy was performed immediately following twice daily $(08: 30 \mathrm{~h}$ and $16: 30 \mathrm{~h})$ treatment with $1 \mathrm{ml}$ or $5 \mathrm{ml} \mathrm{bFF}$ or control plasma for 24 or $48 \mathrm{~h}$. In another group of ewes, the time to the onset of oestrus was determined after 3 days of once daily $(08: 30 \mathrm{~h})$ treatment with $5 \mathrm{ml}$ control plasma, $5 \mathrm{ml} \mathrm{bFF}, 5 \mathrm{ml}$ bFF previously heated to $90^{\circ} \mathrm{C}$ for $45 \mathrm{~min}$ and the cooled, or $5 \mathrm{ml} \mathrm{bFF}$ plus $1000 \mathrm{i}$.u. PMSG (Folligon: Intervet International B.V., Boxmeer, The Netherlands) or 1000 i.u. hCG (Gonadotraphon L.H.: Paines \& Byrne Ltd, Greenford, U.K.). In a final group of ewes, once daily treatment with $5 \mathrm{ml}$ bFF or control plasma was continued for 27 days, laparoscopy being performed on the day of the last injection. In those ewes, blood samples $(08: 30 \mathrm{~h}$ and $16: 30 \mathrm{~h})$ were taken the day before the start of the injections (Day 0), once daily (08:30 h) for the next 3 days (Days 1-3) and thrice weekly thereafter until Day 49 of the experiment.

All blood samples collected were centrifuged at $1200 \mathrm{~g}$ for $15 \mathrm{~min}$ at $4^{\circ} \mathrm{C}$. The plasma was removed and stored frozen $\left(-20^{\circ} \mathrm{C}\right)$ until assayed for $\mathrm{FSH}$, luteinizing hormone (LH) and progesterone by radioimmunoassay.

\section{Ovarian dissection and in-vitro studies}

Immediately after ovariectomy of bFF-treated and control ewes, the corpora lutea and all antral follicles $\geqslant 1.0 \mathrm{~mm}$ in diameter were individually dissected from each pair of ovaries into sterile Medium 199 with Earle's salts supplemented with Hepes buffer $(20 \mathrm{~mm})$, gentamicin $(50 \mu \mathrm{g} / \mathrm{ml}$ : Gibco, Grand Island, New York, U.S.A.), sodium heparin (50 i.u./ml: Weddel Pharmaceuticals Ltd, London, U.K.) and 1.0\% bovine serum albumin (Fraction V; Sigma Chemical Co, St Louis, MO, U.S.A.) (Medium A). After recording the follicular diameter and examining the thecal vasculature, each follicle was incised to release its contents. The released follicular fluid was examined for the presence or absence of debris, aspirated through a fine-bore capillary tube and stored frozen $\left(-20^{\circ} \mathrm{C}\right)$ until assayed for oestradiol-17 $\beta$. The internal face of the follicle wall was washed gently and repeatedly with $2 \mathrm{ml}$ Medium A and the released clumps of granulosa cells were dispersed by pipetting several times through a finely drawn Pasteur pipette. The oocyte was isolated and assessed subjectively as being healthy or degenerate as previously described (McNatty et al., 1983). The follicle wall was washed several times more, and the total number of granulosa cells in the pooled washings was counted using a haemocytometer. The colour of the theca interna was noted. On the basis of its morphological appearance, each follicle was classified as non-atretic or atretic (McNatty et al., 1984). Follicles considered to be non-atretic were those with: visible thecal capillaries when viewed at $\times 10$ magnification under a dissecting microscope, no debris in the follicular fluid, an oocyte of healthy appearance, $\geqslant 26 \%$ of the maximum number of recoverable granulosa cells for a follicle of a given size, and a pink to red theca interna. Follicles were considered to be atretic when one or more of these 5 criteria was not applicable.

The ability of granulosa cells to metabolize testosterone to oestradiol-17 $\beta$ (aromatase activity) and to produce adenosine $3^{\prime}, 5^{\prime}$-monophosphate (cAMP) in response to challenge with LH or FSH was determined as described previously (Henderson, Kieboom, McNatty, Lun \& Heath, 1985). To obtain sufficient cells from each pair of ovaries to perform replicate determinations it was often necessary to pool cells from follicles of a similar size and classification. Granulosa cells from follicles $1-2.5 \mathrm{~mm}$ in diameter were always pooled, cells from follicles $3-4.5 \mathrm{~mm}$ in diameter were occasionally pooled while cells from follicles $\geqslant 5 \mathrm{~mm}$ in diameter were never pooled. After collecting the granulosa cells, and pooling when appropriate, each sample of cells was split into 2 fractions. The cells were centrifuged at $200 \mathrm{~g}$ for $10 \mathrm{~min}$ and resuspended in Dulbecco's phosphate-buffered saline containing $0.1 \%$ bovine serum albumin (DBS-BSA) for determining the cAMP response to challenge with LH or FSH, or in Medium A devoid of sodium heparin (Medium 
B) for determination of aromatase activity. Aliquants of each were taken for determination of cell number by haemocytometer counts. To determine cAMP production in response to $\mathrm{LH}$ and FSH, aliquants of granulosa cells $\left(150 \times 10^{3}\right)$ in $0.5 \mathrm{ml}$ DBS-BSA were dispensed into $10 \times 75 \mathrm{~mm}$ tubes containing $0.5 \mathrm{ml}$ DBS-BSA or $0.5 \mathrm{ml}$ of a solution of ovine FSH (NIADDK-oFSH-16, $200 \mathrm{ng} / \mathrm{ml}$ ) or ovine LH (NIADDK-oLH-23, $200 \mathrm{ng} / \mathrm{ml}$ ). The tubes were capped and incubated at $37^{\circ} \mathrm{C}$ for $1 \mathrm{~h}$ in a shaking water bath before being transferred to an $80^{\circ} \mathrm{C}$ water bath for $15 \mathrm{~min}$. Some tubes were transferred directly to the $80^{\circ} \mathrm{C}$ bath so that the endogenous cAMP content of the cells at zero time could be determined. All the tubes were frozen $\left(-20^{\circ} \mathrm{C}\right)$ until assayed for cAMP production by radioimmunoassay. Preliminary studies showed that cAMP production by granulosa cells incubated at $37^{\circ} \mathrm{C}$ was constant for $2 \mathrm{~h}$.

For determination of aromatase activity, aliquants of cells $\left(60-600 \times 10^{3}\right)$ in $0.5 \mathrm{ml}$ Medium B were pipetted into $10 \times 75 \mathrm{~mm}$ plastic tubes containing $0.5 \mathrm{ml}$ of a solution of testosterone $(2 \mu \mathrm{g} / \mathrm{ml})$ in Medium B. The tubes were gassed with $5 \% \mathrm{CO}_{2}$ in air, capped and incubated for $3 \mathrm{~h}$ at $37^{\circ} \mathrm{C}$ in a shaking water bath. At the end of the incubation, the tubes were snap frozen to $-70^{\circ} \mathrm{C}$. Subsequently the tubes were thawed, centrifuged for $15 \mathrm{~min}$ at $1500 \mathrm{~g}$ and the supernatants assayed for oestradiol-17 $\beta$. Preliminary studies indicated that the aromatase reaction was constant over the $3 \mathrm{~h}$ period.

\section{Radioimmunoassays}

FSH, LH and progesterone were measured in plasma by specific radioimmunoassays described previously (Scaramuzzi, Caldwell \& Moor, 1970; Salamonsen et al., 1973; McNatty, Gibb, Dobson, Thurley \& Findlay, 1981).

The standard FSH preparation was NIH-FSH-S11 and Papkoff preparation G4-150C was used as the iodinated tracer. The FSH antiserum was rabbit anti-human FSH (Butt, M94) and was used at an initial dilution of 1:8000. Its cross-reaction with ovine LH (NIH-LH-S21), ovine prolactin (NIH-P-S18), ovine growth hormone (NIH-GH-S11) and ovine thyroid stimulating hormone (NIH-TSH-S 8 ) was $<0.5 \%$. The sensitivity of the assay was $10 \mathrm{ng} \mathrm{FSH} / \mathrm{ml}$ plasma. The intra- and inter-assay coefficients of variation were $6 \%$ and $9 \%$ respectively.

The $\mathbf{L H}$ antibody raised in a rabbit against NIH-LH-S11 was used at an initial dilution of 1:40 000. The LH antiserum exhibited low cross-reactions with other pituitary hormones: ovine prolactin (NIH-P-S12) $0.09 \%$; ovine thyroid-stimulating hormone (NIH-TSH-S8) 2.4\%; ovine growth hormone (NIH-GH-S1 1 ) $0.4 \%$; ovine FSH (NIH-FSH-S10) $0.4 \%$. The pituitary LH preparation for both the standard and the iodinated tracer was NIH-LH-S11. The sensivity of the assay was $0.2 \mathrm{ng} \mathrm{LH} / \mathrm{ml}$ plasma and the intra- and inter-assay coefficients of variation were $7 \%$ and $11 \%$ respectively.

Progesterone was extracted from plasma with petroleum ether and measured using an antiserum (WA-26) raised in an ovariectomized ewe against progesterone-11 $\alpha$-hemisuccinate conjugated to bovine serum albumin. The extraction efficiency was monitored by the addition of tritiated progesterone, and the mean recovery was $82 \%$. The antiserum was used at an initial dilution of $1: 10000$ and major cross-reacting steroids were $11 \alpha$-hydroxyprogesterone $(120 \%), 11 \beta$-hydroxyprogesterone $(25 \%)$, 20 $\alpha$-dihydroprogesterone $(3.5 \%)$ and androstenedione $(0 \cdot 4 \%)$. The sensitivity of the assay was $0.2 \mathrm{ng} / \mathrm{ml}$ plasma, and the intra- and inter-assay coefficients of variation were $<10 \%$.

Oestradiol-17 $\beta$ was measured directly in aliquants of follicular fluid and Medium B (the aromatase assay solution) by radioimmunoassay as described previously (McNatty et al., 1981, 1984). The oestradiol-17 $\beta$ antiserum (WA-27) was raised in an ovariectomized ewe against oestradiol-6-(O-carboxymethyl) oxime conjugated to bovine serum albumin. The antiserum was used at an initial dilution of $1: 16000$ and major cross-reacting steroids were oestrone $(7 \%)$, oestriol $(1 \%)$ and oestradiol- $17 \alpha(1 \%)$. The sensitivity of the assay (per tube) was $5 \mathrm{pg}$ and the intra- and inter-assay coefficients of variation were $<11 \%$. 
Cyclic AMP was assayed directly in aliquants of DBS-BSA by radioimmunoassay as described previously (Harper \& Brooker, 1975; Henderson et al., 1985). The cAMP antibody was generated in a rabbit using $\mathrm{O}^{2}$-monosuccinyl-adenosine $3^{\prime}, 5^{\prime}$-monophosphate coupled to bovine serum albumin as the antigen. The gamma globulin fraction was prepared from the serum and used in the radioimmunoassay at an initial dilution of 1:10000. Relative cross-reactivity of the cAMP antibody with AMP, ADP, ATP, or cGMP was $<0.0015 \%$. The sensitivity of the assay (per tube) was $2.5 \mathrm{fmol}$ and the intra- and inter-assay coefficients of variation were 7 and $14 \%$ respectively.

\section{Statistics}

For analysis, plasma concentrations of FSH and LH in each ewe from the first day of treatment with $\mathrm{bFF}$ or plasma onwards were transformed to a percentage of the mean plasma value on the day before treatment (i.e. Day 0). To avoid making assumptions about the normality of the distribution of this transformation, the transformed data were analysed by non-parametric statistics using the Wilcoxon rank-sum test, or the Kruskal-Wallis test with multiple comparisons between treatments being made using a test based on differences between rank sums (Conover, 1980). The FSH and LH data have therefore been presented as medians and range. Other data were analysed by analysis of variance in conjunction with the Newman-Keuls test, Student's $t$ test or $\chi^{2}$ as appropriate. When heterogeneity of variance was indicated by Bartlett's test, the data were transformed to logarithms to equalize the variances before statistical analysis. In these instances the data have been presented as geometric means together with $95 \%$ confidence limits. The level of significance was set at $P<0.05$.

\section{Results}

Effect of 3 days treatment with bFF on plasma gonadotrophin concentrations, time to oestrus and ovulation rate

Figure 1 shows the effect on plasma concentrations of LH, FSH and progesterone of administration of $5 \mathrm{ml} \mathrm{bFF}$ to ewes twice daily for 3 days, starting from the time of initiation of luteolysis with cloprostenol. In bFF-treated ewes, median concentrations of FSH, but not LH, fell rapidly and were significantly lower than those of the plasma treated control ewes from $8 \mathrm{~h}$ after the first injection to Day 4 of the experiment. Thereafter median levels of FSH in the bFF-treated ewes 'rebounded', and on Days 5-7, they were significantly higher than those of the control ewes. Median levels of LH were also significantly higher than those of control ewes on Days 4-8.

After the injection of cloprostenol, plasma progesterone concentrations declined in a similar fashion in control and bFF-treated ewes. In the controls, the plasma progesterone concentrations had risen markedly by Day 9 to levels indicative of the formation of new corpora lutea; in these ewes oestrus occurred $2 \cdot 2 \pm 0 \cdot 2$ (mean \pm s.e.m.) days after cloprostenol treatment. In the bFF-treated ewes, the plasma progesterone concentrations were still at basal levels on Day 9; in these ewes oestrus did not occur until $10 \cdot 5 \pm 0.9$ days after cloprostenol treatment.

The above effects of bFF treatment on plasma gonadotrophin concentrations were dose-related (Fig. 2). The lowest median FSH values in response to bFF treatment on Days 1-3 occurred on Day 3, and the 'rebound' in FSH and rise in LH levels occurred during Days 5-8. Twice daily injection of $0.5 \mathrm{ml}$ was the minimum dose of bFF which significantly suppressed plasma FSH concentrations, relative to values in control $(0 \mathrm{ml} b F F)$ ewes. The lowest median levels were achieved with $5.0 \mathrm{ml} \mathrm{bFF}$ administered twice daily. Twice daily injections of $1.0 \mathrm{ml} b F F$ was the minimum dose causing a significant 'rebound' in FSH and rise in LH levels on Day 5, although by Day 7 the FSH concentrations had returned to control values. The rebound in FSH after injections of $5.0 \mathrm{ml}$ bFF once or twice daily was comparable to that achieved with $1.0 \mathrm{ml} \mathrm{bFF}$ twice daily, but of longer 

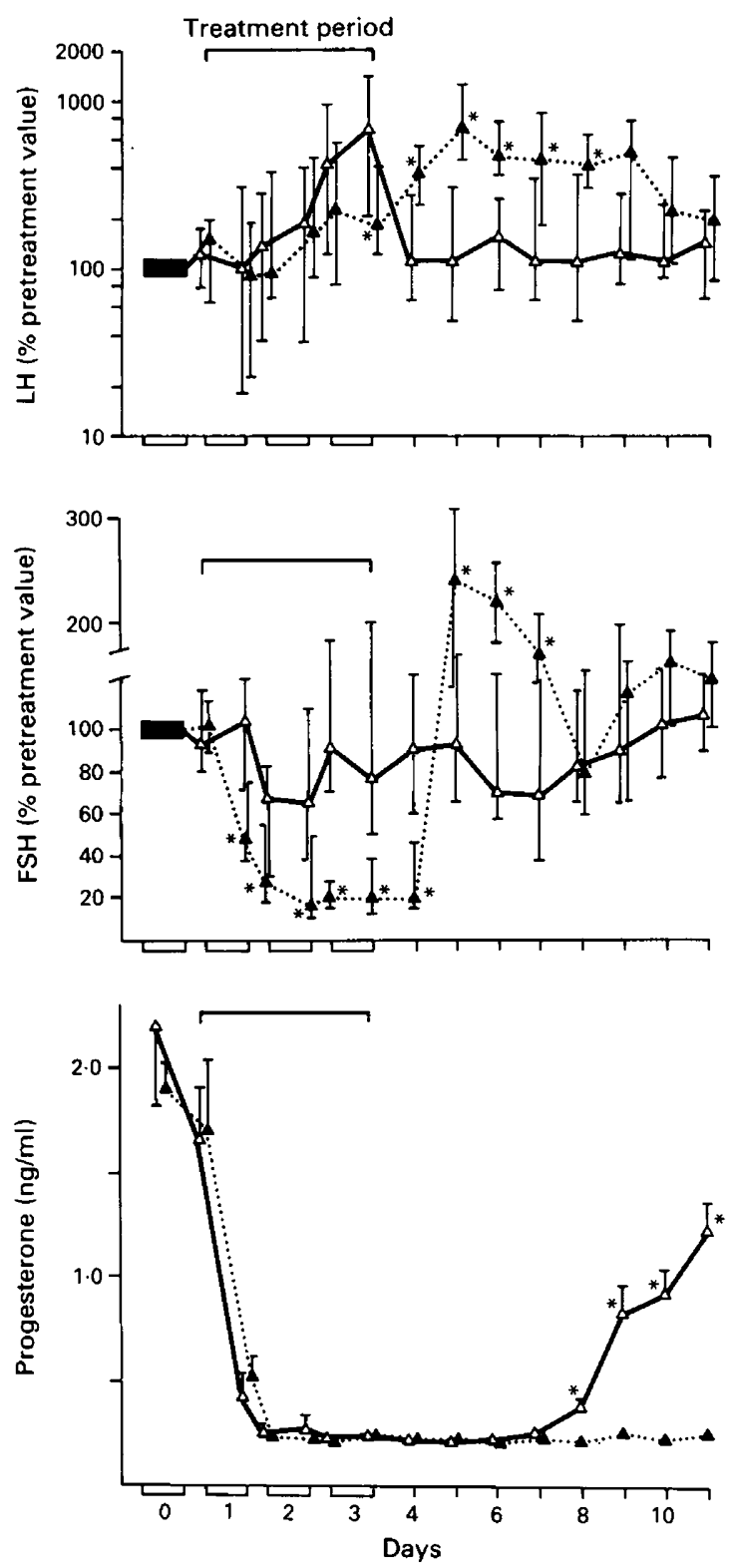

Fig. 1. Plasma concentrations of $\mathrm{LH}, \mathrm{FSH}$ and progesterone in Romney ewes treated with bovine follicular fluid ( $5 \mathrm{ml}$ twice daily, $\mathrm{N}=4, \Delta \ldots \Delta$ ) or plasma $(\mathrm{N}=8, \Delta-\Delta)$. LH and FSH values are medians with the range indicated by vertical lines. Progesterone values are means with vertical lines showing the s.e.m if larger than the symbol for the mean value. Asterisks indicate significant differences $(P<0.05)$ between the 2 groups on the same day.

duration, with elevated concentrations of FSH (relative to control ewes) still apparent on Day 7. By Day 9 there were no significant differences in plasma concentrations of FSH or LH between any of the groups.

The increase in time to oestrus after 3 days of bFF treatment was also dose-related (Table 1), $0.5 \mathrm{ml}$ fluid injected twice daily being the lowest dose able to delay the onset of oestrus. The conse- 
quent delay in formation of new corpora lutea was reflected in the plasma progesterone concentrations on Day 11 (Table 1). Between Days 0 and 7 there were no significant differences in plasma progesterone concentrations between any of the bFF doses (see Fig. 1 for mean progesterone values for 0 and $5.0 \mathrm{ml}$ fluid twice daily). Therefore, the dose-related delay to oestrus was not a consequence of the bFF interfering with the cloprostenol-induced luteolysis.

Although none of these doses of $b F F$ that were administered had a significant effect on ovulation rate (Table 1), the mean ovulation rates of ewes receiving $1.0 \mathrm{ml} \mathrm{bFF}$ twice daily, or 5.0 once daily, were $64 \%$ higher than that of control ewes (Table 1). When these 2 dose regimens were administered to a larger group of ewes, a significant increase in ovulation rate was observed (Table 2).

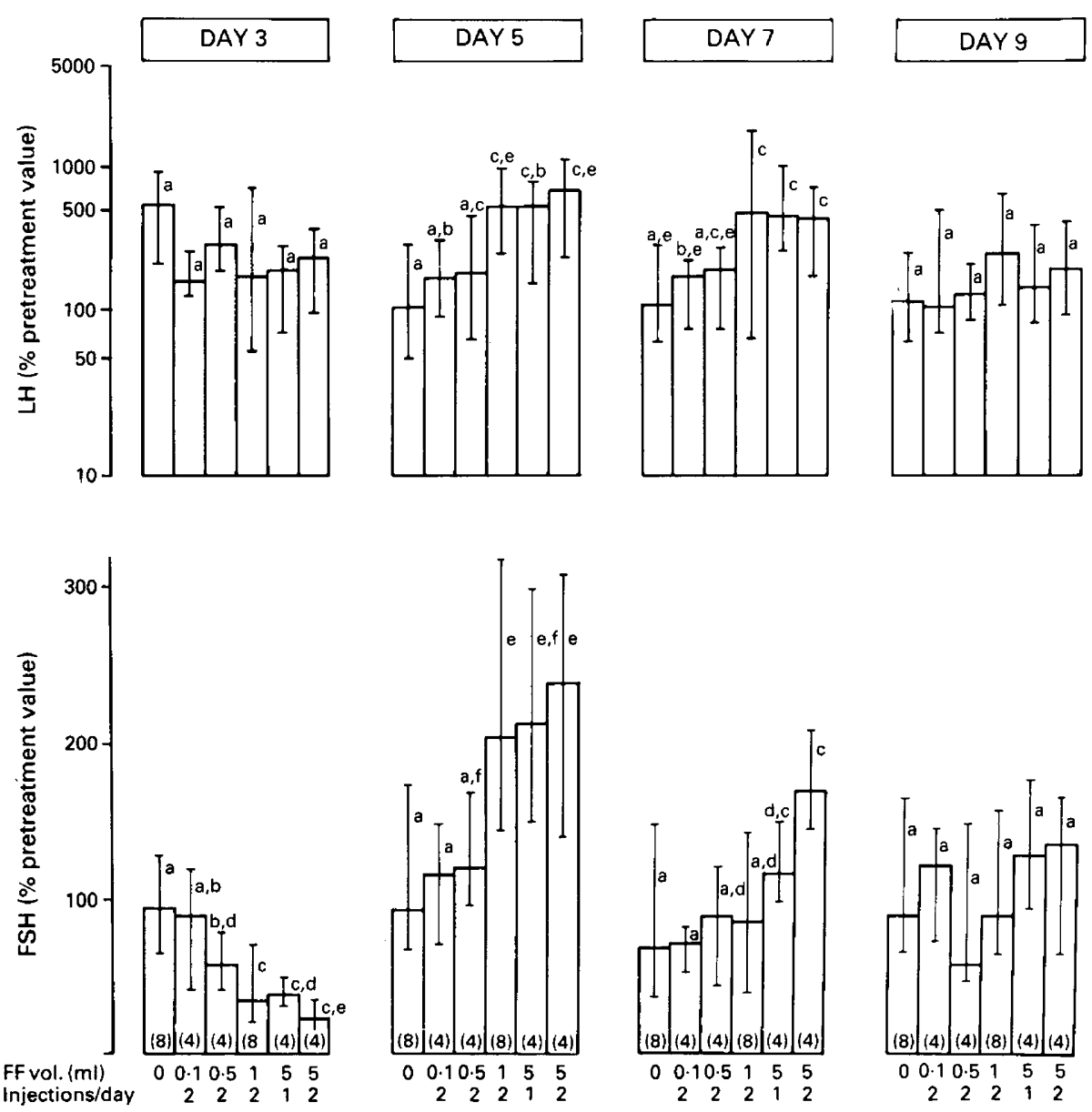

Fig. 2. Effect of different doses of bovine follicular fluid on plasma levels of LH and FSH. Values are medians of $(\mathrm{N})$ sheep with the vertical lines showing the range. Median values with different letters within the same day are significantly different: ab, bc, $P<0.05$; ae, $P<0.02$; ac, de, dc, $P<0.01$.

The pretreatment plasma concentrations of FSH and LH did not differ significantly between the groups. The values for ewes treated with $0,0 \cdot 1,0 \cdot 5,1 \cdot 0$ or $5.0 \mathrm{ml} \mathrm{bFF}$ once daily and $5 \cdot 0 \mathrm{ml} b F F$ twice daily were $130 \pm 17,138 \pm 38,161 \pm 34,106 \pm 20,107 \pm 22$ and $130 \pm 21 \mathrm{ng} \mathrm{FSH} / \mathrm{ml}$ respectively (mean \pm s.e.m.) and $0 \cdot 7 \pm 0 \cdot 1,0 \cdot 6 \pm 0 \cdot 1,0 \cdot 6 \pm 0 \cdot 1$, $0 \cdot 5 \pm 0 \cdot 1,0 \cdot 7 \pm 0 \cdot 2$ and $0 \cdot 6 \pm 0 \cdot 1 \mathrm{ng} \mathrm{LH} / \mathrm{ml}$ respectively. 
Table 1. Effect of treatment with bovine follicular fluid on time to oestrus, plasma progesterone concentrations and ovulation rate in Romney ewes

\begin{tabular}{|c|c|c|c|c|}
\hline $\begin{array}{l}\text { Dose of follicular } \\
\text { fluid }\end{array}$ & $\begin{array}{l}\text { No. } \\
\text { of } \\
\text { ewes }\end{array}$ & $\begin{array}{l}\text { Days to oestrus } \\
\text { after injection } \\
\text { of cloprostenol }\end{array}$ & $\begin{array}{c}\text { Plasma } \\
\text { progesterone } \\
(\mathrm{ng} / \mathrm{ml} \text { ) on } \\
\text { Day } 11\end{array}$ & $\begin{array}{l}\text { Ovulation } \\
\text { rate }\end{array}$ \\
\hline None & 8 & $2 \cdot 2 \pm 0 \cdot 2^{\mathrm{a}}$ & $1 \cdot 22 \pm 0 \cdot 12^{\mathrm{a}}$ & $1 \cdot 4 \pm 0.3$ \\
\hline $0.1 \mathrm{ml}$, twice daily & 4 & $2 \cdot 3 \pm 0 \cdot 2^{a}$ & $1 \cdot 20 \pm 0 \cdot 11^{\mathrm{a}}$ & $1 \cdot 5 \pm 0 \cdot 3$ \\
\hline $0.5 \mathrm{ml}$, twice daily & 4 & $4.8 \pm 0.5^{b}$ & $0.58 \pm 0 \cdot 16^{\mathrm{b}}$ & $1.5 \pm 0.5$ \\
\hline $1.0 \mathrm{ml}$, twice daily & 8 & $7 \cdot 3 \pm 0 \cdot 3^{c}$ & $0.27 \pm 0.03^{c}$ & $2 \cdot 3 \pm 0 \cdot 4$ \\
\hline $5.0 \mathrm{ml}$, once daily & 4 & $8 \cdot 0 \pm 0 \cdot 4^{c}$ & $0.34 \pm 0.06^{\mathrm{c}}$ & $2 \cdot 3 \pm 0 \cdot 3$ \\
\hline $5.0 \mathrm{ml}$, twice daily & 4 & $10.5 \pm 0.9^{d}$ & $0.23 \pm 0.02^{c}$ & $1 \cdot 5 \pm 0.3$ \\
\hline
\end{tabular}

Values are mean \pm s.e.m. Ewes were injected with bFF for 3 days beginning immediately after injection of cloprostenol on Day 10 of the oestrous cycle. Mean values with different superscripts in the same column are significantly different $(P<0.01$ for days to oestrus, $P<0.025$ for progesterone concentrations). Ovulation rates did not differ significantly between the treatments.

Table 2. Frequency table showing the effect of treatment with bovine follicular fluid on ovulation rates in Romney ewes

\begin{tabular}{lcccccc}
\hline \multirow{2}{*}{$\begin{array}{l}\text { Dose of follicular } \\
\text { fluid }\end{array}$} & 1 & 2 & 3 & 4 & 5 & $\begin{array}{c}\text { Mean ovulation } \\
\text { rate } \pm \text { s.e.m. }\end{array}$ \\
\cline { 2 - 7 } None & 23 & 10 & 2 & 0 & 0 & $1 \cdot 4 \pm 0 \cdot 1$ \\
I ml, twice daily & 10 & 19 & 3 & 1 & 1 & $1.9 \pm 0 \cdot 2$ \\
5 ml, once daily & 6 & 14 & 4 & 1 & 0 & $2 \cdot 0 \pm 0 \cdot 2$ \\
\hline
\end{tabular}

Ewes were injected with bFF for 3 days starting immediately after administration of cloprostenol to initiate luteolysis on Day 10 of the oestrous cycle. $\chi^{2}$ analysis indicates that both doses of bFF significantly increased ovulation rate $(P<0.005)$. Ovulation rate frequencies did not differ significantly between the 2 doses of $b F F$.

The ability of $5 \mathrm{ml} \mathrm{bFF}$ to delay the onset of oestrus when given once daily for 3 days from the start of luteolysis $(7 \cdot 5 \pm 0 \cdot 2$ vs $2 \cdot 2 \pm 0.2$ days to oestrus for treated and control ewes respectively; mean \pm s.e.m., $\mathrm{N}=5$ ) was lost if the bFF had previously been heated to $90^{\circ} \mathrm{C}$ for $45 \mathrm{~min}$ $(2 \cdot 6 \pm 0 \cdot 2$ days to oestrus, $N=5)$ or if it was administered with 1000 i.u. PMSG $(2 \cdot 1 \pm 0 \cdot 1$ days to oestrus, $N=5$ ). Simultaneous administration of $1000 \mathrm{i} . \mathrm{u}$. hCG failed to overcome the effects of the bFF $(6 \cdot 8 \pm 0 \cdot 5$ days to oestrus, $N=5)$.

\section{Follicular characteristics after treatment with $b F F$}

The results of Fig. 3 show the consequence at the ovarian level of treatment with bFF. Ewes were injected twice daily $(08: 30$ and $16: 30 \mathrm{~h})$, from the time they received cloprostenol, with $5 \mathrm{ml}$ $\mathrm{bFF}$ for 24 or $48 \mathrm{~h}$ or $1 \mathrm{ml} \mathrm{bFF}$ for $48 \mathrm{~h}$ ( 4 ewes for each time and dose of bFF). The ewes were then ovariectomized. No significant differences were observed between the doses of bFF or the time of treatment and so the ovarian data obtained from the bFF-treated ewes have been pooled. The ovarian data obtained from the control ewes which received plasma from an ovariectomized cow for 24 or $48 \mathrm{~h}$ ( 4 ewes at each time) have also been pooled because no significant differences were observed between the 2 time periods. Treatment with bFF had no significant effect on the number of small $(1-2.5 \mathrm{~mm})$, medium $(3-4.5 \mathrm{~mm})$ or large $(\geqslant 5 \mathrm{~mm})$ diameter ovarian antral follicles present (Fig. 3). Moreover, the mean diameter of the largest follicles $\geqslant 5 \mathrm{~mm}$ diameter in the bFF-treated ewes $(6.6 \pm 0.2 \mathrm{~mm}$, mean \pm s.e.m., $\mathbf{N}=10)$ did not differ significantly from that in 
the control ewes $(6.9 \pm 0.3 \mathrm{~mm}, \mathrm{~N}=8)$. In addition, $b F F$ treatment had no significant effect on the mean number of follicles in each size grouping considered to be non-atretic by their morphological characteristics. The mean \pm s.e.m. numbers of small, medium and large non-atretic follicles were $6 \pm 1,1 \cdot 1 \pm 0.4$ and $1 \cdot 1 \pm 0 \cdot 2$ respectively in the control ewes $(\mathrm{N}=8)$ and $7 \pm 2,1.8 \pm 0.8$ and $0.6 \pm 0.2$ respectively in the bFF-treated ewes $(\mathrm{N}=12)$. In large follicles, bFF treatment resulted in there being significantly fewer granulosa cells per follicle $(P<0.01)$, a significantly lower concentration of oestradiol-17 $\beta$ in follicular fluid $(P<0.05)$ and a significant reduction in the capacity of the granulosa cells to aromatize testosterone to oestradiol-17 $(P<0.05)$ and to produce cAMP in response to challenge with LH or FSH $(P<0.001)$ (Fig. 3). No significant effect of bFF on any of these characteristics was observed in small or medium-sized follicles.
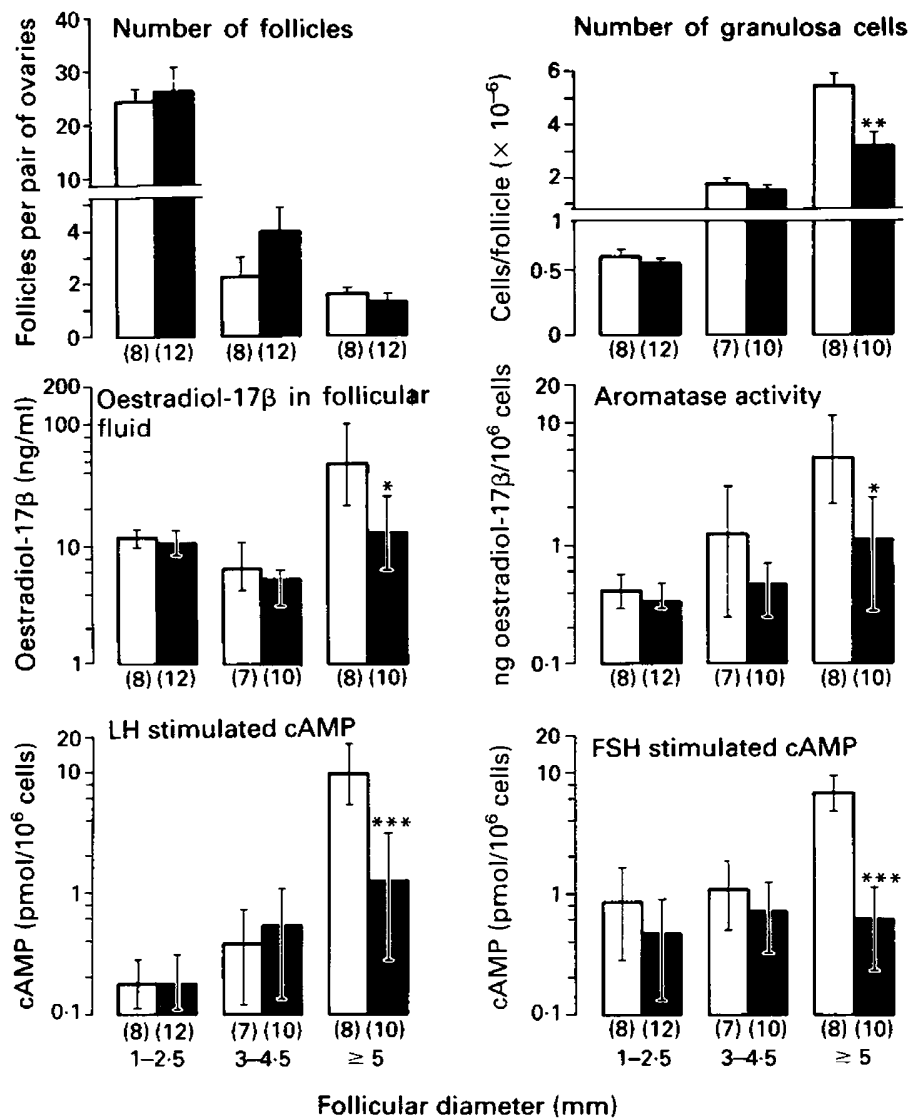

Fig. 3. Effect of bFF treatment on the number of ovarian follicles, the number of granulosa cells per follicle, oestradiol-17ß concentrations in follicular fluid, the aromatase activity of granulosa cells and the ability of granulosa cells to produce cAMP in response to challenge with LH and FSH ( $\square$ control ewes, $\square$ bFF-treated ewes).

Data showing follicle and granulosa cell numbers have been presented as means with vertical lines indicating the s.e.m. The remaining data have been presented as geometric means with $95 \%$ confidence limits indicated by the vertical lines. Numbers in parentheses refer to the number of sheep studied. Asterisks indicate significant differences between control and bFF-treated ewes for follicles $\geqslant 5 \mathrm{~mm}$ in diameter $\left({ }^{*} P<0.05,{ }^{* *} P<0.01,{ }^{* * *} P<0.001\right)$. The endogenous cAMP content of the granulosa cells was $0 \cdot 19 \mathrm{pmol} / 10^{6}$ cells (geometric mean value) with $95 \%$ confidence limits at $0 \cdot 16$ and $0 \cdot 22 \mathrm{pmol} / 10^{6}$ cells. 

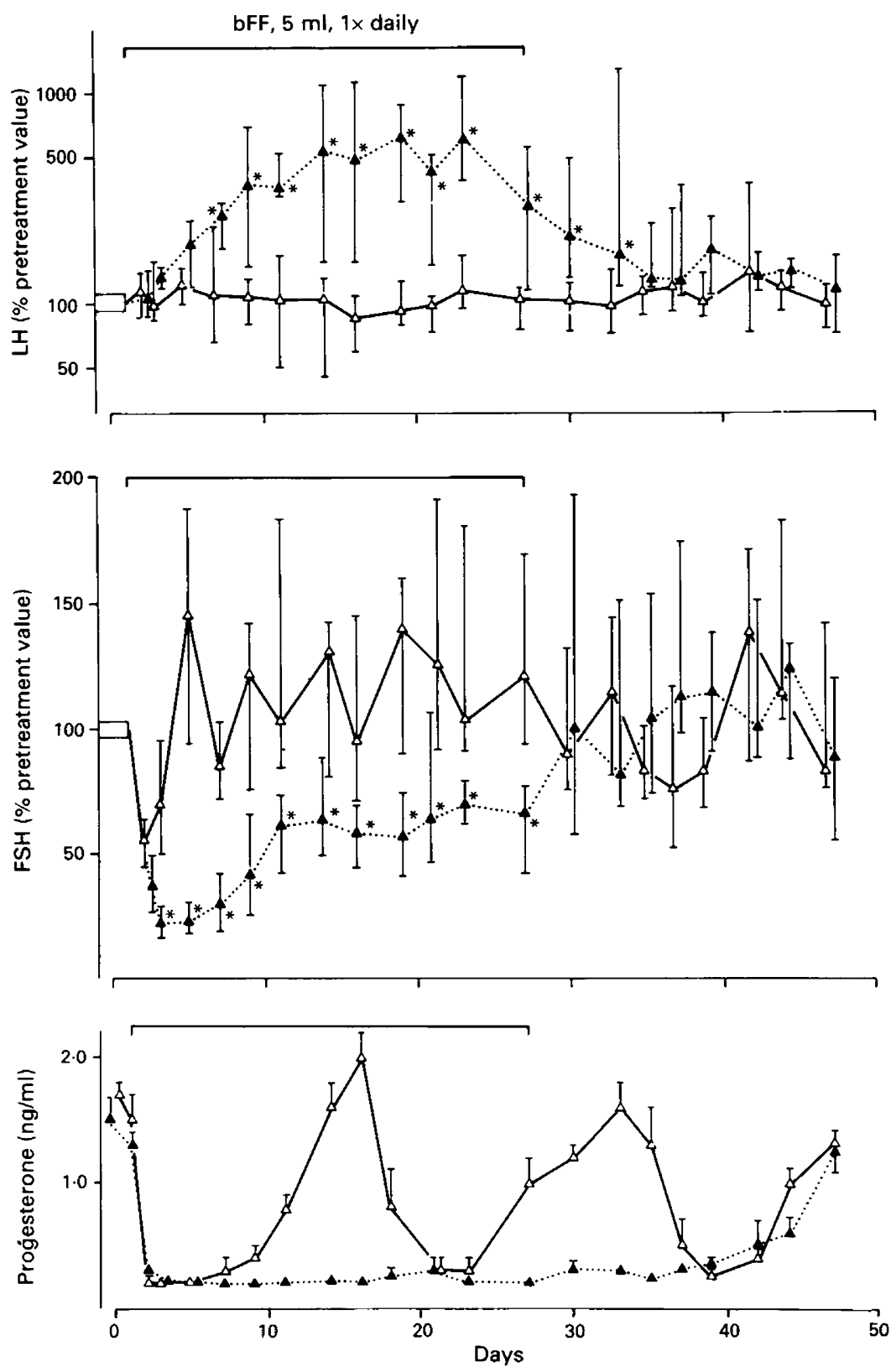

Fig. 4. Plasma concentrations of LH, FSH and progesterone in ewes treated daily for 27 days with $5 \mathrm{ml} \mathrm{bFF}(. \Delta \ldots \Delta ., \mathrm{N}=5$ ) or plasma from an ovariectomized cow (control ewes, $\triangle-\triangle$, $\mathrm{N}=5$ ). Treatment started immediately after injection of cloprostenol to initiate luteolysis on Day 10 of the oestrous cycle (Day 1 of the experiment). LH and FSH values are medians with the range shown by vertical lines. Asterisks indicate significant differences $(P<0.05)$ between the 2 groups on the same day. Progesterone values are means with vertical lines showing the s.e.m. when larger than the symbol for the mean value. Pretreatment plasma gonadotrophin concentrations did not differ significantly between the 2 groups. Values (mean \pm s.e.m.) were $0 \cdot 5 \pm 0 \cdot 1$ and $0 \cdot 4 \pm 0 \cdot 1 \mathrm{ng} \mathrm{LH} / \mathrm{ml}$ and $120 \pm 13$ and $127 \pm 19 \mathrm{ng} \mathrm{FSH} / \mathrm{ml}$ for the control and bFF-treated ewes respectively. 


\section{Effect of 27 days treatment with bFF on ovarian function}

Figure 4 shows the effect on plasma LH, FSH and progesterone concentrations of once daily injections of $5 \mathrm{ml}$ bFF for 27 days, starting from the initiation of luteolysis with cloprostenol. By Day 3, median plasma FSH concentrations in the bFF-treated ewes had fallen to $20 \%$ of the pretreatment values. Thereafter, median values rose gradually to reach about $60 \%$ of pretreatment levels by Day 11 where they stayed for the remainder of the treatment period. Median plasma concentrations of $\mathrm{LH}$, in contrast to those of FSH, gradually rose about 5-fold during the first 14 days of the treatment period and stayed at this level for most of the remainder of the treatment period. Oestrus was not observed in the bFF-treated ewes during the 27 -day treatment period. There was also no evidence of ovulation occurring, as indicated by the absence of visible corpora lutea at laparoscopy at the end of the treatment period, and low concentrations of plasma progesterone throughout the treatment period. In contrast, control ewes displayed oestrus on Days 3 and Days 19-20, and their plasma progesterone concentrations were consistent with normal ovarian cyclicity. At the end of the treatment period, median plasma FSH concentrations in the bFF-treated ewes rose to control levels within 3 days, and median LH concentrations fell to control values within 8 days. Oestrus was observed in all 5 ewes between Days 36 and 41. Plasma progesterone concentrations also gradually rose to normal luteal values. All the control and bFF-treated ewes were successfully mated with a fertile ram at the first oestrus after the treatment period, and subsequently each ewe delivered a single lamb.

\section{Discussion}

Although the effects of treatment of ewes with bovine follicular fluid on plasma concentrations of gonadotrophins and oestrous cycle length have been studied before (Miller et al., 1979; Miller, Critser \& Ginther, 1982; Cummins et al., 1983; McNeilly, 1984) the dose-dependency of observed effects or the consequence at the ovarian level of follicular fluid treatment have not been reported hitherto. The dose-related increase in time to oestrus after bFF administration was probably a consequence of the suppression of plasma FSH concentrations; the lower FSH concentrations were the longer oestrus was delayed. Moreover, simultaneous administration of PMSG, which is rich in FSH activity, with bovine follicular fluid prevented the increase in time to oestrus. Behavioural oestrus is an event dependent upon the large amounts of oestradiol- $17 \beta$ produced by a follicle as it attains ovulatory maturity. One would predict, therefore, that the increase in time to oestrus occurs as a consequence of the low plasma FSH concentrations in follicular fluid-treated ewes reducing follicular production of oestradiol-17 $\beta$. This was confirmed by examination of the ovaries of treated ewes. Compared to control ewes, large follicles in these ewes had lower concentrations of oestradiol- $17 \beta$ in follicular fluid, fewer granulosa cells, and the granulosa cells had a reduced ability to aromatize androgen to oestradiol-17 $\beta$ (Fig. 3). In addition, the granulosa cells produced reduced amounts of cAMP when challenged with FSH or LH; a high production of cAMP in response to FSH is necessary for maximum follicular oestradiol-17 $\beta$ biosynthesis (Henderson et al., 1985). Granulosa cell proliferation, follicular oestradiol biosynthesis and the development of granulosa cell responsiveness to FSH and LH (as measured by cAMP production in this study) are each FSH-dependent events (Henderson, 1979; Richards, 1979). Therefore, the effects on large follicles are consistent with their being exposed to inadequate levels of FSH due to the suppression of plasma FSH concentrations by follicular fluid treatment. It is, however, possible that bovine follicular fluid might also have directly inhibited FSH action at the ovary. Treatment with follicular fluid had no significant effects on small or medium-sized follicles (Fig. 3). Perhaps early follicular growth (from small to medium sizes) is less critically dependent upon FSH than later growth (from medium to large sizes).

Another consequence of the deleterious effects of follicular fluid treatment on large antral follicles, which are the major sources of follicular oestradiol-17 (McNatty et al., 1984) and inhibin 
(Tsonis et al., 1983; Henderson et al., 1984), would be a reduction in the negative feedback effects of oestradiol-17 $\beta$ and inhibin on pituitary gonadotrophin secretion. This could account for the elevation in plasma LH concentrations (Figs 1,2 \& 3) and for the rebound in FSH values which occurred when treatment was stopped (Figs $1 \& 2$ ). As normal follicular development resumed when treatment ceased, the increased output of follicular oestradiol-17 $\beta$ and inhibin would subsequently reduce pituitary gonadotrophin output once more to 'normal' physiological levels.

An important result from the 3-day treatments with bovine follicular fluid was the increased frequency of multiple ovulations observed with doses of $1 \mathrm{ml}$ twice daily, or $5 \mathrm{ml}$ once daily (Table 2). Wallace \& McNeilly (1985) have also reported that treatment with bovine follicular fluid can increase ovulation rates in sheep. However, in that study, ewes of the prolific Damline breed were used, and relatively high doses of follicular fluid ( $10 \mathrm{ml}$ intravenously twice daily) were given for 11 days during the luteal phase. In the present study, the increased ovulation rate followed treatment with relatively small amounts of follicular fluid for only 3 days after the start of luteolysis. Administration of FSH or substances with FSH-like activity will increase ovulation rate in sheep (Wright et al., 1981; Boland et al., 1983; Kelly et al., 1983; McNatty et al., 1985). Perhaps the elevated plasma concentrations of FSH and LH occurring on cessation of treatment allowed a greater than normal number of follicles to attain ovulatory maturity in synchrony in some ewes, hence the increased frequency of multiple ovulations.

Ewes were rendered temporarily infertile during 27 days of continuous, daily treatment with bovine follicular fluid; oestrus did not occur and ovulation was prevented. The low plasma concentrations of FSH occurring during the treatment period causing abnormal follicular development was probably the underlying cause of the infertility. After cessation of treatment, FSH and LH concentrations returned to pretreatment values and oestrus, mating and conception occurred; no adverse post-treatment effects on fertility were noted. The lowest median values of FSH ( $\sim 20 \%$ of pretreatment levels) occurred 3-5 days after treatment began. Thereafter, median concentrations gradually rose to reach $\sim 60 \%$ of pretreatment levels by Day 11 and remained at this value for the remainder of the treatment period. This partial loss in the FSH-suppressing capacity of bovine follicular fluid, which has been noted in monkeys (Channing, Tanabe, Turner \& Hodgen, 1982b) and rats (Thomas \& Nikitovitch-Winer, 1984), may represent the development of refractoriness to the treatment. Alternatively, the initial low levels of plasma FSH may be the result of pituitary FSH secretion being suppressed by a combination of the effect of bovine follicular fluid and negative feedback by follicular steroids and inhibin. As follicular development becomes impaired by the low levels of FSH, the ovarian negative-feedback effects would be lessened, thereby allowing a partial increase in pituitary FSH secretion.

The component(s) of follicular fluid responsible for the effects observed in this study is unknown, but inhibin would seem a likely candidate. Inhibin is a heat-labile product of granulosa cells which inhibits pituitary FSH production and is present in high concentrations in follicular fluid (Henderson \& Franchimont, 1981, 1983; Tsonis et al., 1983; Henderson et al., 1984). However, the possibility of other components in follicular fluid being responsible, perhaps by acting directly on the ovary, cannot be excluded. In summary, the results of this study support the view that follicular fluid components may have potential usefulness as agents to increase fertility, through increasing ovulation rate, or to impair fertility, by preventing ovulation.

We thank NIADDK, NIH, Bethesda, U.S.A. for ovine pituitary gonadotrophins; Dr W. Butt (University of Birmingham, U.K.) for the rabbit antiserum to human FSH; Dr H. Papkoff (University of California, U.S.A.) for the FSH preparation G4-150C; Marion Gibb for performing the FSH assay; Mr G. Aliprantis for assistance in obtaining ovaries from Wellington abattoir for the collection of follicular fluid; and the Wallaceville farm staff for care of the sheep. 


\section{References}

Boland, M.P., Crosby, T.F. \& Gordon, I. (1983) Ovarian response in ewes following horse anterior pituitary extract and progestagen treatment. Anim. Reprod. Sci. 6, 119-127.

Channing, C.P., Anderson, L.D., Hoover, D.J., Kolena, J., Osteen, K.G., Pomerantz, S.H. \& Tanabe, K. (1982a) The role of non-steroidal regulators in control of oocyte and follicular maturation. Recent Prog. Horm. Res. 38, 331-408.

Channing, C.P., Tanabe, K., Turner, C.K. \& Hodgen, G.D. (1982b) Antisera to porcine follicular fluid in monkeys: neutralization of human and pig inhibin activity in vivo and in vitro. J. clin. Endocr. Metab. 55, $481-486$.

Conover, W.J. (1980) In Practical Nonparametric Statistics, 2 edn, pp. 229-237. John Wiley \& Sons, New York.

Cummins, L.J., O'Shea, T., Bindon, B.M., Lee, V.W.K. \& Findlay, J.K. (1983) Ovarian inhibin content and sensitivity to inhibin in Booroola and control strain Merino ewes. J. Reprod. Fert. 67, 1-7.

Harper, J.F. \& Brooker, G. (1975) Femtomole sensitive radioimmunoassay for cyclic AMP and cyclic GMP after $2^{\prime} \mathrm{O}$-acetylation by acetic anhydride in aqueous solution. J. cyclic Nucleotide Res. 1, 207-218.

Henderson, K.M. (1979) Gonadotrophic regulation of ovarian activity. Br. med. Bull. 35, 161-166.

Henderson, K.M. \& Franchimont, P. (1981) Regulation of inhibin production by bovine ovarian cells in vitro. J. Reprod. Fert. 63, 431-442.

Henderson, K.M. \& Franchimont, P. (1983) Inhibin production by bovine ovarian tissues in vitro and its regulation by androgens. $J$. Reprod. Fert. 67, 291-298.

Henderson, K.M., Franchimont, P., Charlet-Renard, Ch. \& McNatty, K.P. (1984) Effect of follicular atresia on inhibin production by bovine granulosa cells in vitro and inhibin concentrations in the follicular fluid. $J$. Reprod. Fert. 72, 1-8.

Henderson, K.M., Kieboom, L.E., McNatty, K.P., Lun, S. \& Heath, D.A. (1985) Gonadotrophin-stimulated cyclic AMP production by granulosa cells from Booroola $\times$ Romney ewes with and without a fecundity gene. J. Reprod. Fert. 75, 111-120.

Kelly, R.W., Owens, J.L., Crosbie, S.F., McNatty, K.P. \& Hudson, N.L. (1983) Influence of Booroola Merino genotype on the responsiveness of ewes to pregnant mares serum gonadotrophin. Anim. Prod. Sci. 6, 199-207.

Kling, O.R., Roche, P.C., Campeau, J.D., Nishimura, K., Nakamura, R.M. \& Di Zerega, G.S. (1984) Identification of a porcine follicular fluid fraction which suppresses follicular response to gonadotrophins. Biol. Reprod. 30, 564-572.

Ledwitz-Rigby, F., Rigby, B.W., Gay, V.L., Stetson, M.C., Young, J. \& Channing, C.P. (1977) Inhibitory action of porcine follicular fluid upon granulosa cell luteinization in vitro. Assay and influence of follicular maturation. J. Endocr. 74, 175-184.

McNatty, K.P., Gibb, M., Dobson, C., Thurley, D.C. \& Findlay, J.K. (1981) Changes in the concentration of gonadotrophic and steroidal hormones in the antral fluid of ovarian follicles throughout the oestrous cycle of the sheep. Aust. J. biol. Sci. 34, 67-80.
McNatty, K.P., Hillier, S.G., van den Boogaard, A.J.M., Trimbos-Kemper, T.C.M., Reichert, L.E. \& van Hall, E.V. (1983) Follicular development during the luteal phase of the human menstrual cycle. J. clin. Endocr. Metab. 56, 1022-1034.

McNatty, K.P., Hudson, N.L., Henderson, K.M., Lun, S., Heath, D.A., Gibb, M., Ball, K., McDiarmid, J.M. \& Thurley, D.C. (1984) Changes in gonadotrophin secretion and ovarian antral follicular activity in seasonally breeding sheep throughout the year. $J$. Reprod. Fert. 70, 309-321.

McNatty, K.P., Hudson, N., Gibb, M., Ball, K., Henderson, K.M., Heath, D.A., Lun, S. \& Kieboom, L.E. (1985) FSH influences follicle viability, oestradiol biosynthesis and ovulation rate in Romney ewes. $J$. Reprod. Fert. 75, 121-131.

McNeilly, A.S. (1984) Changes in FSH and the pulsatile secretion of $\mathrm{LH}$ during the delay in oestrus induced by treatment of ewes with bovine follicular fluid. $J$. Reprod. Fert. 72, 165-172.

Miller, K.F., Critser, J.K., Rowe, R.F. \& Ginther, O.J. (1979) Ovarian effects of bovine follicular fluid treatment in sheep and cattle. Biol. Reprod. 21, 537-544.

Miller, K.F., Critser, J.K. \& Ginther, O.J. (1982) Inhibition and subsequent rebound of FSH secretion following treatment with bovine follicular fluid in the ewe. Theriogenology 18, 45-53.

Richards, J.S. (1979) Hormonal control of ovarian follicular development: a 1978 perspective. Recent Prog. Horm. Res. 35, 343-373.

Salamonsen, L., Jonas, H.H., Burger, H.C., Buckmaster, J.M., Chamley, W.A., Cumming, I.A., Findlay, J.K. \& Goding, J.R. (1973) A heterologous radioimmunoassay for follicle stimulating hormone: application to measurements of FSH in the ovine estrous cycle and in several other species including man. Endocrinology 93, 610-618.

Scaramuzzi, R.J., Caldwell, B.V. \& Moor, R.M. (1970) Radioimmunoassay of $\mathbf{L H}$ and estrogen during the estrous cycle of the ewe. Biol. Reprod. 3, 110-119.

Sluss, P.M., Fletcher, P.W. \& Riechert, L.E. (1983) Inhibition of ${ }^{125}$ I-human follicle stimulating hormone binding to receptor by a low molecular weight fraction of bovine follicular fluid: inhibitor concentration is related to biochemical parameters of follicular development. Biol. Reprod. 29, 1105-1113.

Thomas, C.L. \& Nikitovitch-Winer, M.A.B. (1984) Complete suppression of plasma follicle-stimulating hormone in castrated male and female rats during continuous administration of porcine follicular fluid. Biol. Reprod. 30, 427-433.

Tsonis, C.G., Quigg, H., Lee, V.W.K., Leversha, L., Trounson, A.O. \& Findlay, J.K. (1983) Inhibin in individual ovine follicles in relation to diameter and atresia. J. Reprod. Fert. 67, 83-90.

Wallace, J.M. \& McNeilly, A.S. ( 1985) Increase in ovulation rate after treatment of ewes with bovine follicular fluid in the luteal phase of the oestrous cycle. $J$. Reprod. Fert. 73, 505-515.

Wright, R.W., Bondioli, K., Grammer, J., Kuzan, F. \& Menino, A. (1981) FSH or FSH + LH superovulation in ewes following estrus synchronization with medoxyprogesterone acetate pessaries. J. Anim. Sci. 52, $115-118$. 